\title{
Contribution of E. L. Wheelwright to Political Economy: Public Scholar, Economic Power and Global Capitalism
}

\author{
Phillip Anthony O'Hara*
}

\begin{abstract}
In this paper I examine the contribution of Edward Lawrence Wheelwright (1921-2007) to political economy and start by highlighting the important role that Wheelwright played as a Public Scholar and contributor to the building of institutions. This is followed by an overview of his analysis of the major contradictions of capitalism. Consideration is then given to his work on the concentration of economic power and transnational capitalism. In the last major section I scrutinise his history of capitalism in Australia, which is set within a political economy framework and its global and regional contexts. In the conclusion an assessment is made of his contribution to political economy, with suggested areas of further inquiry also identified.
\end{abstract}

\section{$1 \quad$ Public Scholar and Building Institutions}

Ted Wheelwright was born on 19 August 1921 into a working class family in the 'old' Ecclesall Bierlow Ward, Sheffield. ${ }^{2}$ He had two sisters, one older and one younger than him. His father was a 'working class Tory'; while his mother, Gladys (née Kirk), was a dedicated homemaker who worked for a time as a shop assistant, being more sympathetic to the plight of the working class than his father. Neither of his parents was educated, either formally or informally, and his father 'got very upset' when he brought left-wing ideas and people into the household during his teenage years. ${ }^{3}$

This was a very poor family, and his father was unemployed 'the whole time he was in high school' (Wheelwright 2000, p.714). His father's civilian employment was interrupted, first by active service in the First World War, and again due to many years of unemployment during the Great Depression. The young Ted Wheelwright gained a scholarship to attend high school, and, due to family poverty, his parents had an argument about whether he could go to high school: his mother won the argument, 'otherwise I wouldn't be here' (Wheelwright \& Kuhn 1990, p. 3). Out of necessity, therefore, he left school in 1937, at the age of 16, and became a bank clerk to supplement his family's paltry unemployment relief. $\mathrm{He}$ gained a Certificate of Commerce as part of a correspondence course to advance his promotional and employment prospects.

He left the banking industry in 1941 to undertake active service in the Royal Air Force (1941-46), rising to the rank of Squadron Leader. He was awarded the Distinguished Flying Cross (DFC) in 1943 for his 'acts of valour, courage or devotion to duty whilst flying in active operations against the enemy' (Yahoo Answers.com 2009). During the war he also specialised in providing instruction to his fellow nightraiders 'in the arcane skills of navigating night bombers over Europe', which, he said, was extremely helpful in teaching him the importance of lucidity and specificity in teaching (Wheelwright 2000, p. 716). He became radicalised by his war service, especially due to the active class structure among servicemen, including the officers' privileges while the 'rank-and-file' suffered, which 'was enough to turn anybody into a bolshie' (Wheelwright \& Kuhn 1990, p. 5). 
After the war, Wheelwright used his war service scholarship to attend university. In the choice of university he saw, again, the operation of class privilege and prestige. He first applied to Cambridge University, but the colleges there placed a lot of emphasis on 'old school tie' connections: one college was willing to put him up if he practised the Anglican religion, but he refused to do so. He finally chose the University of St Andrews in Scotland, which was very helpful to returned servicemen, graduating with first class honours in the Masters of Arts of economics and politics (1949). His motivation for studying economics and politics was to understand the factors behind unemployment, war and social cleavage. Specifically, why was it that so many workers, including his father, were unemployed for so long? Why is war service so well remunerated relative to normal working class civilian remuneration? Why do class distinctions penetrate every aspect of social reality? (Wheelwright \& Kuhn 1990.)

As a radical, he saw the social economy as one indivisible whole. He thus came to view economics, politics and society as inextricably related, a view reinforced by his experience of war, depression and family poverty. When he gained his first academic job as a Teaching Fellow and an Assistant Lecturer at the University of Bristol (1949-52), he was especially impressed with the research and teaching of a colleague, Henry Douglas Dickinson (1899-1969), who wrote a number of books and research articles, including Institutional Revenue: A Study of the Influence of Social Institutions (1932) and The Economics of Socialism (1939). Wheelwright noted Dickinson's 'socialis[m] sprung from the middle class, a genuine scholar of the old school who, besides being an economist, was a mathematician who could handle the transformation problem and a historian who could cope with the history of capitalism' (Wheelwright 2000, p. 715).

With the exception of Dickinson, however, Wheelwright was not very impressed with the economics taught at Bristol, as it was more directed to orthodox theory than to the institutional foundations of political economy processes. However, he did undertake quite a few classes for workers, such as the miners in South Wales, and learnt that the first principle of a Public Scholar is humility, since some of the workers knew more about Marx's Capital than he did. 'That was a great lesson', and he was forever indebted to Dickinson for pointing it out to him (Wheelwright \& Kuhn 1900, p. 14). Not seeing much of a future, either for the British academy or for his place within it, he looked around for a better environment, and eventually chose the University of Sydney, Australia, where he worked as a Lecturer in Economics (1952-57), Senior Lecturer (1957-65) and Associate Professor (1965-86). He was passed over six times for promotion to Professor, 'on the last occasion sparking a public controversy', resulting in 'Forty parliamentarians sign[ing] a petition calling on the University to change its decision' (Stilwell 2007, pp. 2-3).

At the University of Sydney and during his retirement from teaching, Wheelwright produced 23 books or monographs, 52 journal articles or book chapters, several dozen public lectures and radio/television broadcasts; plus contributions to university governance through the Staff Club, the Association of University Teachers and the Sydney University Senate. He also wrote, edited and contributed to the publication of dozens of books and articles on transnational corporations. He taught in a variety of units in the Department of Economics, including industrial economics, history of political economy, economic policy, international economics and introductory lectures in political economy. ${ }^{4}$ Wheelwright provided the spur and focal point around which the political economy 
courses were developed at Sydney, and which now constitute a well-developed program of study at the undergraduate, honours, masters and $\mathrm{PhD}$ levels. In this context, a number of volumes emerged, including two books of Readings in Political Economy (Wheelwright \& Stilwell 1976a,b), and six books of Essays in the Political Economy of Australian Capitalism (Wheelwright \& Buckley 19751987). In honour of his contributions to political economy at the University of Sydney there is now an annual E. L. Wheelwright Award for the best student of political economy, and the E.L. Wheelwright Memorial Lecture in Political Economy, designed 'to promote public discussion in Australia about contemporary political economic issues' (SUW 2008), the first of which was given by Walden Bello (2008), and the second by Jim Stanford (2009).

Wheelwright served on two federal government committees, the Scott Inquiry into Procurement Policy (1974) and the Jackson Committee Inquiry into the Manufacturing Sector (1974-75). ${ }^{5} \mathrm{He}$ also served on two boards, the Commonwealth Banking Corporation Board (1975-80) and the New South Wales Government Overseas Trade Authority Board (1979-82). For decades he worked informally for many Australian Labor Party (ALP) members of parliament and ministers, providing advice, writing speeches and contributing to policy. These included, among others, Arthur Calwell, Bill Hayden, Jim Cairns, Rex Connor, Gough Whitlam and Bob Hawke. His influence on ALP policy, especially in the 1960 s and 1970s, and to some degree into the early-mid 1980s, was significant, especially in the areas of corporate ownership and control, economic planning and community participation in governance. ${ }^{6} \mathrm{He}$ also contributed to editorial tasks linked to policy by being, for instance, on the board of The Journal of Economic and Social Policy (during 1995-2002).

He became a Rockefeller Fellow in Social Sciences at Harvard University (1958), which also enabled him to do research at universities in Toronto, London, New Delhi and Jakarta. Later he was an invited Professor in Malaysia $(1962,1984)$, Argentina (1965-66), the Moscow Institute of Economics (1966), Peking Academy of Sciences (1966-67), University of Chile (1970-71) and the USSR Academy of Sciences (1983). In this period there was considerable interest in Wheelwright's knowledge about foreign investment, transnational corporations, industrial organisation and associated public policies, in Australia (especially before and during the Whitlam Government [1972-75]) as well as in the developing world of Asia and Latin America. Of all his works, the book he co-authored on The Chinese Road to Socialism (Wheelwright \& McFarlane 1969) received the most international interest, being mostly sympathetically reviewed in numerous academic journals.

This knowledge and notoriety enabled him to gain considerable long-term funding for the Transnational Corporations Research Project (TCRP), a research institute that he established and directed at the University of Sydney from 1975 until 1992. In this capacity he variously wrote, edited, coordinated and produced 20 books, 26 research monographs, 10 Occasional Papers, 21 Working Papers, and 5 Data Papers specifically for the TCRP, working alongside Greg Crough (his former student), who was for many years the TCRP Senior Researcher (see TCRP 1989 for details). These works made contributions to knowledge in the areas of corporate power, foreign investment, financial institutions and socioeconomic development in a number of nations and regions. Perhaps the most ambitious of these was the nine-volume Transnational Corporations in South East Asia and the Pacific, (Utrecht 1978-1986; Wheelwright 1988; Stauffer 1988). These volumes 
did nothing less than provide a history of transnational corporations throughout much of Asia and the Pacific, written from a political economy perspective where, among other things, consideration is given to the impact of transnational corporations on local and regional populations.

The contributions Wheelwright made to academic life and public governance in Australia and overseas were extensive. As a Public Scholar, he sought to communicate with the public, including interested but non-academic audiences, students, academics, policy-makers and business people. The depression, war and postwar instabilities taught him to be a man of action, so that when he was not navigating bombing raids over Germany he was talking with workers about capital; being seen on television or heard on radio providing a radical perspective on events; being asked by politicians to provide advice; being paid by capitalists to research transnational companies; discussing political economy with students; improving governance in academia; or undertaking research on the structure of power in society. While doing this he also 'helped develop the Australian Consumers Association, the University Cooperative Bookshop, the University of Sydney Staff Club, and the Sydney Association of University Teachers' (Stilwell 2007). He saw his role as a Public Scholar in the service of humanity, and it is this that made him a proactive interpreter of political economy for the community.

\section{Contradictions of Capitalism}

Wheelwright's analysis of the contradictions of capitalism followed from his interdisciplinary exposure to ideas and methods of analysis. He used the notion of contradiction in a multifarious manner, variously drawing from Thorstein Veblen, Karl Marx, John Maynard Keynes, Joseph Schumpeter, John Kenneth Galbraith and others. In general terms, however, the foundations of his analysis of contradictions can be best understood by examining the work of Karl Polanyi, whom he mentions numerous times in his writings. The general notion of contradiction emanates from Polanyi, a figure not well known in political economy circles in Australia in the 1960s and 1970s, but better known now. Polanyi, especially in his now famous book on The Great Transformation (Polanyi 1944), argued that capitalism has an inherent contradiction in its motion which produces a dialectical double-movement, as well as a complicated series of evolutionary transformations to deal with its problematic sources of change. Put simply, he argued that the free-market system cannot exist in the long run in its pure form, since pure markets fail to provide the necessary public goods to ensure their own reproduction.

To understand this process, Polanyi undertook a series of thorough investigations into the functioning of pre-capitalist societies, and found that they always constituted a relatively integrated set of social, political and economic institutions, where economic elements never dominated, and where the social and political aspects were always critical elements of the totality. They thus had an economy embedded in the social and political apparatus. When it came for capitalism to develop, it too required some embedding of its economic elements within its more general political and social elements for society to function effectively. The less than perfect embedding of the economic elements, in turn, gives rise to the tendency for a double movement, namely, that whenever capitalism becomes too unregulated it needs a more balanced system of governance 
of controls and stability mechanisms, and whenever it becomes too regulated and bureaucratic, similarly it needs a movement back towards a more balanced system of governance. Historically, therefore, the system of policy and governance typical of capitalist development has moved from eras of deregulation to regulation and back to deregulation and then later regulation, as the various pathdependent changes provide feedback loops and complex responses to these movements. $^{7}$

It is simply not possible to have perfect and stable systems of capitalist development and evolution, as the complex interaction of its parts gives rise to lags and jarring adjustments. Non-equilibrium processes are thus typical of its motion, and therefore a method based on evolutionary transformation and circular and cumulative causation is necessary for comprehending its dynamics. For instance, the tendency for overproduction in major capitalist economies from the 1870s to the 1890s was followed by a counter tendency in which more business-oriented institutions emerged during the late 1890s and into the early 1900s (Veblen 1923). Similarly, the relatively deregulated systems of capitalist policy that dominated in the 1920s, and culminated in the Great Depression, were followed by a counter movement towards more institutional and New Deal type arrangements from the 1930s to the early 1970s; and when crisis set in from the mid-1970s, the existing 'bastard Keynesian' system of governance was blamed, leading to a counter movement towards the more neoliberal 'deregulation' that prevailed during the mid-to-late 1970s through to the 1990s. ${ }^{8}$ Later, when neoliberal forces deregulated finance too much, the subprime crisis of 2008-2009 was followed by more regulation, as the counter double movement came back into play.

That Wheelwright should utilise Polanyi's notion of the disembedded economy is not surprising, since he was influenced not only by neo-Marxian themes, but also by institutionalist ideas. He was initially introduced to Veblen's ideas through reading the pages of Monthly Review when he was at Harvard in the late 1950s (particularly the work by Paul Sweezy), as well as Gunnar Myrdal, Adolf Lowe and of course Galbraith. It was therefore not surprising that a section of Polanyi's The Great Transformation, entitled 'The Market and the Separation of Economics and Politics', was included in volume 1 of the Readings in Political Economy (Wheelwright \& Stilwell 1976a). ${ }^{9}$ This excerpt was specifically on the notion of the disembedded economy, namely, that land, labour and money are 'fictitious commodities', requiring special attention by the state or the community in order to ensure their reproduction in the long term. Wheelwright, along with Polanyi, recognised that we need institutions to protect land, labour and money from the unstable vicissitudes of the free market. Land needs a protector to prevent massive environmental degradation from the exploitation of resources characteristic of market tendencies. Labour needs protection from the periodic tendency of markets to pay wages below subsistence levels, and from accidents and anomalous work conditions. Also, as already noted, money and finance must be protected from the tendency of speculative bubble crashes, insolvencies and crises typical of free banking and lightly regulated systems.

Wheelwright also discussed Polanyi's disembedded economy in an article on 'Capitalism and Social Decay' (Wheelwright 1974b), reprinted in Capitalism, Socialism and Barbarism (Wheelwright 1978), where he specifically deals with the 'central contradiction of capitalist society', in which the free market 'eroded social and community life, and caused cultural degradation'. Here he recognises that the ideology of individualism and competition, if left to its own devices, will tend to 
destroy the very fabric of society and community, also producing extreme loneliness and inequality as social life is unravelled by constant change and instability. As he concludes in this essay, "As long as competitive motivational patterns, rooted in individualism, remain dominant, ... the social decay of capitalist society will continue' (p. 161). This resonates well with recent research on the decline in trust, sociality, environmental resources and financial stability typical of free-market governance through neoliberalism (see O'Hara 2006c, ch. 10). ${ }^{10}$

One of Wheelwright's key themes is the contradiction between global and national capitalism, a core theme typically investigated by political economists. Here he often explored the hypothesis of the relationship between the revolutionary transformation of the global economy and its impact on various national and regional economies (Wheelwright 2001a,b). Indeed, this is the central thesis of the work undertaken in the Transnational Corporations Research Project. His academic work on foreign investment (Wheelwright 1963) presents this relationship as a complex array of forces in an environment of inadequate information and data. But in his more popular works, such as Fitzpatrick and Wheelwright (1965) and Crough and Wheelwright (1982), he is blunt and argues forcefully at times that the relationship between the global and national forces often results in the fragmentation of local economies. In arguing this, Wheelwright was decades ahead of his time, as this theme has become a core concern of many contemporary scholars. It can be seen in relation to the deregulation of the financial system, and its destabilising impact on national economies; revolutions in technology, productivity and consumption which have been destroying critical forms of ecological capital; and changing forces of hegemony in the world economy, vis-à-vis Britain, the US, Japan and China (for instance), which also can result in the deterioration of the local culture. Wheelwright has often been criticised as an economic nationalist, even by Marxists (such as Dick Bryan), but through time his analysis, while often popularly written, presaged what has become a standard radical critique of neoliberalism and globalisation, when one sees it as a contradiction linked to the disembedded economy and the double movement. ${ }^{11}$

\section{Economic Power and Transnational Corporations}

One of the most important subjects of analysis undertaken by Wheelwright concerned the concentration of economic and political power. This is but one element of Polanyi's disembedded economy, namely, that people try to protect themselves from the market by accumulating power in order to prevent the dislocation typical of free markets. Wheelwright got the same idea from Marx's work, especially volume one of Capital (Marx 1867). This idea links to the concentration of ownership and centralisation of location in certain areas such as industrial and knowledge centres. He was also influenced by Veblen's Theory of Business Enterprise (1905) and Absentee Ownership (1923), Berle and Means's The Modern Corporation and Private Property (1932), Baran and Sweezy's Monopoly Capital (1965), and Galbraith's The New Industrial State (1967). The tendency for capitalism and markets to become more concentrated and centralised is certainly one of Wheelwright's major emphases, being studied in some depth, for instance, in his very early work on Ownership and Control of Australian Companies (1957), followed by the Anatomy of Australian Manufacturing Industry (1967, with Judith Miskelly), plus later work in his Radical Political Economy 
(1974), Australia and World Capitalism (1980, edited with Crough and Wilshire) and Australia: A Client State (1982, with Crough). Much of this research was also relevant to the work in his TCRP research institute.

His 1957 study scrutinised the largest 102 public companies, while the 1967 study concentrated on the largest 299 manufacturing corporations. Three main hypotheses were examined in these two books. The first concerned the degree of concentration or oligopoly, both of them finding a higher (and likely rising) level of concentration (in terms of assets or income) in Australian relative to the UK and the US. The second examined the form of control, whether shareholders or managers, foreign or national, corporate or family. Both studies confirmed that corporate (essentially managerial) control was high and becoming higher through time. The high level of corporate control was mainly due to greater levels of foreign control of Australian companies, with US control rising relative to British. The 1950s and 1960s saw an unprecedented expansion of US interests in Australia, especially in motor vehicles, oil and chemicals, metals, agricultural equipment and food processing, while traditional UK interests were in oil and chemicals, metals, iron and steel, textiles and food processing (p. 3).

The third hypothesis examined the significance of the findings, which was explored in more detail in the 1967 book. The main conclusions were that the change from private to corporate (managerial) control did not fundamentally affect the objectives of the corporations, which were to expand influence and enhance long-term profit. Hilda Rolfe (1967) also comes to this conclusion in her work on interlocking directors in Australia. This shift to increasing foreign dominance led Wheelwright and Miskelly to conclude that further research needed to be undertaken on the implications of this development for the domestic economy.

The analytical results of Wheelwright's study of economic power were summarised in his 1970 Brian Fitzpatrick Memorial Lecture, entitled 'Concentration of Private Economic Power', which was widely published, such as in the Marxist journal, Arena (Wheelwright 1970), Playford and Kirsner's Australian Capitalism: A Socialist Critique (1972), as well as in his book of essays called Radical Political Economy (Wheelwright 1974). ${ }^{12}$ In this brilliantly salient article, he delineates five dimensions of economic power. The first considers the power of Australia's biggest companies in terms of their share of income (or, alternatively, assets). Wheelwright mentions that in the manufacturing industry in Australia, for instance, in the late 1960s, 'the 151 largest companies account for almost half the income' of this sector; while in mining 'the ten largest accounted for four-fifths' of mining income; in banking and finance 'the largest thirty-one companies accounted for four-fifths'; and in insurance, 'the top twenty took almost three-quarters' of the income of this sector.

The second dimension of concentration ratios is closely linked to the first dimension and is usually expressed as the output share for the biggest four or five firms in the industry. For instance Karmel and Brunt (1962, pp.56-7) mention that in the early 1960s the four biggest firms in each sector variously controlled $40 \%$ of the assets of the financial system, $30 \%$ of mining output and only $8-9 \%$ in retailing. In Australia oligopolistic concentration in the manufacturing sector has historically been higher than in the US or UK, partly due to the limited size of the market.

The third dimension is restrictive trade practices, such as price-fixing arrangements, restriction of supply and other underhand dealings to restrict 
competition. My own study of the brewery industry (O'Hara 1975), using Wheelwright's dimensions of economic power, revealed many such practices, including the use of producer-controlled retail outlets. During the late 1960s and 1970s in Australia these restrictive agreements became more widely recognised, partly due to Wheelwright's influence, resulting in the newly formed federal Labor Government passing the first fully-formed Trade Practices Act of 1974, and instituting consumer protection bureaux, price surveillance authorities, and so forth.

The fourth dimension of power is interlocking directorates. This was carefully studied by his student Hilda Rolfe (1967), who analysed the networks of power existing between business families, friends and associates as an indication of class associations. She researched fifty of the largest Australian companies and found that 'there were 169 directors of these fifty companies who held between them 617 directorships in a total of 325 companies' which 'spread out from the original fifty to encompass another 275 companies', while the 'four banks and the four insurance companies had the greatest spread, for their directors held 130 directorships in other companies' (Wheelwright 1974, p. 119). Georgina Murray (2001) uses this earlier work on interlocking directorships to develop a more sophisticated approach. Analysing the significance of four theories, she supports the notion that interlocking directors tend to promote communication and network supports for business, with core individuals potentially enhancing the cohesion of business interests in more subtle relations of influence and association.

The last dimension of economic power concerns linkages between economic and political power. Rather than being a neutral umpire, Wheelwright found that the state often tends to be strongly linked to business; business and government tend, to varying degrees in different countries, to form a web of strong contacts and relationships. While the traditional Marxian hypothesis that the state invariably acts as a tool of business (which was supported by Veblen 1923) may not be entirely correct, there is still a strong tendency in this direction. Conservative and liberal parties, but also increasingly labor and social democratic governments, have tended to support business through an array of subsidies, business people heading boards of inquiry, contractual arrangements for public spending, and fiscal and monetary policy broadly conceived. Wheelwright recognised that Galbraith's countervailing power may moderate this from time to time, while public-political processes, such as logrolling and other attempts by the state to look after the interests of special groups, may well become important. Nevertheless, there is a strong intersecting co-determined linkage between business and state which often multiplies the power of private interests many-fold.

This work on power is also closely linked to Wheelwright's own research on Australia in the global system, which included his work on foreign investment, the role of the state, imperialism and empire, and, more generally, the influence of overseas hegemonic culture on its important clients in the corporate and business networks and relationships. He always wanted to critically analyse the structure of power in society, and the corporate sector tended to increase its power throughout most countries over the past thirty years. Under neoliberal deregulation, the centripetal development of corporate power penetrated the political and social world. He was always cognisant of the relative lack of power of the exploited, oppressed, and subordinated classes and groups in society.

In his first two books, Wheelwright (1957) and Wheelwright et al. (1967), Wheelwright outlined the ownership and control of Australian industry and, as 
discussed above, focused on the higher degree of foreign ownership and control in certain sectors. In his 'Overseas Investment in Australia' article in Alex Hunter's The Economics of Australian Industry (1963), Wheelwright (1963) presents a very balanced and analytical preview of foreign investment. He noted, concerning these overseas interests, that 'a certain amount of foreign capital is essential for the expansion of a young and growing economy' such as Australia, but that a high level of foreign ownership and control 'raises political and economic issues of the first magnitude' (p. 81). He goes on to indicate potential problems with foreign investment in the form of transfer pricing, repatriated profits, instability in finance and property, overseas debt, balance of payments problems, lack of domestic research and development, higher concentration of industry, taxation concessions, and overseas payments for enterprise and financial fees. These problems are explored in more detail in his co-authored work with Brian Fitzpatrick, The Highest Bidder: A Citizen's Guide to Problems of Foreign Investment in Australia (1965).

The issues of foreign investment and foreign control rose again with a series of articles and books written and edited by Wheelwright in the early 1980s. One co-edited volume called Australia and World Capitalism (Crough, Wheelwright \& Wilshire 1980) studied the more contradictory aspects of globalisation, such as unemployment, migration, inequality, inflation, unionism, mining and socialist policies. The other, which was was co-written with Greg Crough and entitled Australia: A Client State (Crough \& Wheelwright 1982), situates Australia in the global corporate system of deregulation and considers themes relating to the disarticulation of industry, foreign control, taxes and debt, as well as the state; themes directly related to Polanyi's notion of the disembedded economy.

The last important articles written by Wheelwright dealt with the instabilities of the late 1980s and early 1990s. In a series of papers he examines the instability arising from the dynamics of speculative bubbles and deep recessions. Special reference is given to the problem of increasing debt, especially private sector debt, in an environment of financial recklessness and deregulation. He scrutinises the origins of the system of corporate capitalism evolving into depression and war into the 1930s to the 1940s, then the advent of "controlled capitalism' of the 1950s and 1960s. This was followed by the crises of the 1970s, 1980s and 1990s. He argued that the demise of the nation-state as globalisation expanded has made these instabilities deeper than otherwise would have been the case. Synchronised market instability is a crucial theme in these essays. Wheelwright changes focus from the issue of Australia being a dependent nation vis-à-vis global firms and US/Japanese power trends to questions of the impact and nature of globalisation on conditions of crisis and deep recession (Wheelwright 1987, 1991a,b, 1992). This is an advance in Wheelwright's thinking, as it induced him to pay more attention to the accumulation of anomalies in modern capitalism.

\section{$4 \quad$ Political Economy of Australian Capitalism}

The Chinese Road to Socialism: Economics of the Cultural Revolution (Wheelwright \& McFarlane 1971) marks the start of Wheelwright's shift to a more radical trajectory. His next book, Radical Political Economy (Wheelwright 1974), revealed, as the name suggests, an even more radical trend in Wheelwright's thought. This trend continued with a third book somewhat provocatively entitled 
Capitalism, Socialism or Barbarian? (Wheelwright 1978). Global capitalism was undergoing its worst structural crisis since the Great Depression and Second World War, many calling it a long wave downswing, which started in the 1970s and continued through successive crises into the 1980s, 1990s and 2000s. To some degree it represented a structural shift of global power as US hegemony declined in relative terms while certain Asian nations (especially Japan initially but later China and its archipelago) took off into a long wave upswing.

Wheelwright could see these forces at work, as did many other political economists around the world. The changing social forces of the 1960s and 1970s, plus the crises of the mid-1970s, early 1980s, early 1990s, and 2000s had a profound effect in stimulating alternative approaches to political economy. The Australian Political Economy Movement was part of this dynamic, especially at the University of Sydney, where Ted Wheelwright was the main figurehead at the inception of a comprehensive undergraduate program in political economy, which was complemented by $\mathrm{PhD}$ students and even a separate department. Wheelwright was, as Jock Collins, a former student, points out, the 'intellectual mentor' of this push at Sydney, who 'played a significant role in the media ... as an often lone left voice in Australian economic and political debate', and 'continued to be a figurehead for the political economy movement'. Thus 'Ted's legacy of scholarship and teaching ... provided the intellectual grounds on which his younger academic colleagues could stake their fight against the economics orthodoxy' (Collins 2009, p. 51). His political economy colleagues included his close friends Ken Buckley (Department of Economic History) and Frank Stilwell, plus others such as Geelum Simpson-Lee, Gavan Butler, Hugh Pritchard, Louis Haddad, Evan Jones, Margaret Power and Debesh Bhattacherya (see also Jones \& Stilwell 1986).

The most ambitious research project with which Wheelwright was associated was the writing of a political economy history of Australian capitalism, including its linkages to the global and regional economies. Partly this related to the work of the TCRP, but most notably it included the six volume ${ }^{13}$ Essays in the Political Economy of Australian Capitalism, edited with Ken Buckley, as well as the two-volume history of Australian capitalism written with Buckley. The six volumes of papers were a first effort at comprehending the history of Australian capitalism from a very broad political economy perspective. The authors of the essays had little to go on in terms of a tradition of radical political economy in which Australian capitalism is scrutinised, except for a few works such as Brian Fitzpatrick's British Imperialism and Australia, 1783-1833, which was published in 1939, and The British Empire in Australia, 1834-1939, which was published in 1941. The process often required a 'brick and straws' approach, preparing the ground and façade for others to complete the structure.

Buckley and Wheelwright's two-volume history of Australian capitalism was, to a significant degree, built on these essays and amounted to an accessible history that took 'class, capital and the state' seriously. ${ }^{14}$ Specifically, their jointlyauthored publications, No Paradise for Workers: Capitalism and the Common People in Australia 1788-1914 (1988) and False Paradise: Australian Capitalism Revisited 1915-1955 (1998), were written from a 'broadly Marxist perspective' with a political economy emphasis. Buckley tended to write a first draft of the volumes, with Wheelwright commenting on specific economic issues, rewriting, and doing the introductions and conclusions. ${ }^{15}$ Both were Public Scholars committed to communicating with a broad audience. Yet they were able to do this while linking the history of Australian capitalism with many Marxian (and some 
Veblenian and Keynesian) concepts. These include, for instance, class struggle, original accumulation, social and technical relations, cyclical instability and crisis, imperialism, monopoly capital, creative destruction, production, evolution and transformation, distribution and absorption of the economic surplus, and state capitalism. Volume two of False Paradise was not well marketed because of editorial disputes between the authors and the publisher. ${ }^{16}$

The main thing we learn from the scholarly work of Ted Wheelwright is that political economy is best developed within the context of a grand narrative that draws upon the concepts of primary accumulation, capital and labour, the double movement, accumulation and crisis, centralisation and concentration, hegemony and uneven development, plus political and economic democracy. Indeed, these concepts are the core of an alternative political economy of both capitalist and noncapitalist systems. This alternative framework also allows room for the consideration of the interaction between class, ethnicity and gender; culture, norms and capabilities; tastes, endogenous preferences and social individuals; as well as sustainability, complexity and story telling. Wheelwright went some way towards accommodating these more subtle relationships, thanks partly to his institutional method. We need to push this process further. The work of Edward Lawrence Wheelwright is thus a good place to start in recognising the complex interaction between the various parts of the social whole, and in expanding the explanatory power of political economy as a holistic science of society.

\section{Conclusion}

The purpose of this review has been to examine the contribution of Ted Wheelwright to political economy. I started out by focusing on Wheelwright's role as a Public Scholar, one who always saw himself as contributing to practical education through the medium of political economy. His vision was in expressing political economy themes in a way that was comprehensible to the ordinary, concerned, citizen. This emphasis on communication probably started when he taught pilots of bombers how to lead an attack on the German forces, and continued when he 'taught' socialist ideas to the workers during his early teaching years in the UK and found that he learnt much from them. This commitment to public service continued when he moved to Australia in the early 1950s.

Essentially, Wheelwright has sought to isolate and identify the sources of power, inequality and instability in society. His early works studied the degree of ownership and control of Australian industry, with special interest placed on the degree of foreign ownership and control. This led him to start the Transnational Corporations Research Project, which published dozens of excellent studies on the global, regional and national workings of corporate power. This corporate hegemony is closely linked to state power as successive governments have mostly enhanced transnational and domestic corporate interests. Wheelwright opened some important areas of study in relation to the positive and negative impact of foreign investment. Much later he contributed to comprehending the impact of globalisation on socioeconomic performance, including the nature of deep recession and speculative bubble crashes.

Perhaps his main contribution has been to stimulate research on the political economy history of Australian capitalism set in a global and regional environment. This includes his six co-edited and two co-written volumes with Ken Buckley. In undertaking this work he sought mainly to develop a unified historical method for contextualising economic, social and political processes through 
evolutionary transformation. His main influences were a Marxian tradition, with some impact from Veblen (especially), Keynes, Galbraith and Schumpeter. He was also under the influence of Paul Sweezy, Paul Baran, Brian Fitzpatrick, and his colleagues at Sydney University and elsewhere. The core themes developed, for instance, by Buckley and Wheelwright $(1988,1998)$ were those of social class, accumulation, surplus, phases of capitalism, crises and wars, and the role of the state. These two volumes managed to provide a convincing political economy history of the evolution and transformation of capitalism in Australia, in a global setting, and to influence radical historiography into the future.

Four things stand out as being in need of further work as a continuation of Wheelwright's contributions to political economy. The first is the need to synthesise the history of Australian capitalism and then to complete the work into the twenty-first century. This is the core project that still needs to be undertaken. Someone or a group of people need to write a history of capitalism in Australia up to the 2000s, drawing in part on the two volumes by Buckley and Wheelwright, and reviewing their methods and historical analyses in the process.

The second is to deepen the economic power research, paying special attention to concentration ratios, interlocking directorships, domestic, regional and global networks, and political associations. This can then provide a foundation for further work on power, class and accumulation. This is a core area of analysis, which surprisingly is an area overlooked in much social science scholarship in Australia. The notion of 'power', along with class and non-class processes, as well as accumulation, profit and growth, are central areas in need of further investigation in an Australian and wider context.

The third more broadly seeks to scrutinise the local, regional and global networks of corporate linkages with a view to comprehending the contribution of such capitals to domestic growth and development. It also needs to be linked to environmental sustainability, social organisation and culture. Here the central concerns are the relationship between the major institutions and players, and how a regime of accumulation is related to socio-economic processes and real people.

Fourthly, the principles of political economy need to be developed further and applied to core problems in a national, regional and global context. This of course includes the disembedded economy, the structure of power and accumulation, the relationship between capital, labour and the state, and newer themes on gender, class, ethnicity, ecology and new social movements. Uneven development, circular causation and historical specificity are other core areas that need advancement. These grand narratives have a core role to play in political economy, even if a broader canvas needs to be painted for a critical view of modern capitalism and its alternatives.

All-in-all it is clear that Wheelwright has provided a remarkable series of studies devoted to the political economy of Australian capitalism set in the global and regional environment. These studies have been challenging, innovative, certainly provocative, and very often entertaining. He sought to be a Public Scholar, one who would be useful to the community in critically scrutinising power relationships in society. He contributed to knowledge relating to the structure and motion of power in society. He sought to link social, economic and political factors together in an historically-based method that could be applied to most problems. He helped to build courses in political economy, educate students and workers, influence colleagues and administrators, communicate with citizens in the community, and have some say in government. He wanted to bring to the 
attention of everyone the grand narratives of class, state, capital, imperialism and crisis. These themes are likely to be crucial to any future political economy worthy of serious consideration for stimulating progressive change and transformation.

* Global Political Economy Research Unit, Curtin Business School, Curtin University, GPO Box U1987, Perth, Australia. Email: philohara1 @ yahoo.com.

\section{Notes}

1 Phil O'Hara is Professor of Global Political Economy and Governance, in the Global Political Economy Research Unit, Curtin Business School, Curtin University, Perth, Australia. A version of this paper was presented at the $22^{\text {nd }}$ HETSA (History of Economic Thought Society of Australia) Conference, July 2009, University of Notre Dame, Fremantle, Western Australia. Special mention should be given to Frank Stilwell who did a thorough proof and critical review of an earlier version of this paper, raising invaluable points and issues. I also wish to thank the three anonymous referees, plus Jerry Courvisanos, Peter Groenewegen, Stuart Rosewarne, Chris Williams (Truus Timmer), and the editors, Mike McLure and Gregory Moore, for earlier comments. This article is dedicated to the memory of Ted Wheelwright, a lively, interesting, controversial and delightful human being; the 'father' of 'radical political economy' in Australia. For readers who wish to read a much longer version, please contact the author.

2 The reference to the 'old' Ecclesall Bierlow Ward is important because the 'old' ward included some very poor areas, whereas 'newer' Ecclesall landownings include buildings that are more modernistic and which are often surrounded by large gardens or grasslands.

3 This brief account of Wheelwright's life is based on a number of sources, including Wheelwright \& Kuhn (1990), Wheelwright \& Moran (1990) and Wheelwright $(2000 \mathrm{~b}, \mathrm{c})$, as well as personal discussions with him.

4 Mention should also be made to Ted's marriage to Wendy, and their two daughters (Helga and Sarah), five grandchildren (Lisa, Jeremy, Duncan, Nigel and Harriat), and great-grandchild (Alexander). It is very important to note the role played by Chris Williams (her Dutch name is Truus Timmer), who Ted mentioned as being 'my longstanding soulmate and research assistant ... who has typed nearly everything I have ever written' (Wheelwright 2000a).

5 Wheelwright (1997) reviewed the nature of these two committees and emphasised their politico-economic significance. He saw the Jackson Committee as being 'the last throes of local capital, seeking to survive by attempting to engineer a form of Australian capitalism with a human face. It was a failure, swamped by the power of transnational capital and its compradors' (p.27). The Scott Committee, on the other hand, recommended a national procurement body to oversee government purchases, and established a National Procurement Board. Some problems were that the federal public services seemed to prefer overseas purchases and big companies. However, it was indicated that a 'cultural change was required among the 30,000 purchasing officers' before they would begin to act more in the national interest in their purchasing norms (p. 22).

6 The link between Wheelwright and ALP policy in the early 1970s drew Stuart Rosewarne to state: 'I lived in Athens in 2001 and had the opportunity to spend some time with Gough Whitlam. We talked quite a bit about Ted, and Whitlam, in typical Whitlam style, maintained that Ted was invited to contribute [more formally] to the Whitlam Labor government's policy formulation but remained reluctant, or at least 
resistant, to taking up the offer. I sense this was as much about two big men's egos being played out' (Rosewarne 2009).

7 The literature on Polanyi's disembedded economy is quite extensive, but some useful references include Stanfield (1986) and Walter C. Neale (1991).

8 Many political economists argue that deregulation is not actually a movement towards more freedom, even for capital, but is merely a decision-making process whereby power is redirected towards certain vested interests, usually 'business', and thereby represents a process of power consolidation and generation. See Schutz (2001a,b).

9 Where possible, I have cited Wheelwright's journal articles as they appeared in his books of collected essays, rather than as they appeared in the original journals, to save space and to reference the more easily accessed sources. Those interested in the original journal papers per se should consult Wheelwright's books, especially Wheelwright (1974, 1978) and Crough and Wheelwright (1980). After 1980, no books of his essays per se were published, so often it is necessary to cite and access the original journal articles.

10 All of Wheelwright's other usages of 'contradiction' can be analysed within the framework of the disembedded economy and the double movement. This includes, for instance, his discussion of Veblen's conflict between industry and business in the introduction to Hilda Rolfe's book (1967), where industry requires coordination between its constituent parts while business needs to expropriate profit through varying degrees of competition (Wheelwright 1967, p.xvi; reprinted in Wheelwright 1974a, p. 132). Polanyi's thesis also links to Wheelwright's discussion of the global/nation contradiction, a crucial theme in his work, where these "contradictions are having significant repercussions for this kind of international integration[, ...] being accompanied by a kind of national disintegration' (Wheelwright 1974, p. 38), a theme discussed, for instance, in Crough \& Wheelwright (1982) and David and Wheelwright (1989).

11 For instance, there is an enormous literature on this. Some examples include a special issue of the Journal of Human Development (Volume 4, Issue 2, 2003) and O'Hara (2006)

12 I used Wheelwright's broad method of analysing economic power in my $\mathrm{BA}(\mathrm{SocSc})$ thesis at Curtin University (WAIT as it was then called) on economic power in the brewery industry (O'Hara 1975).

13 The sixth volume on the media was not technically part of the series entitled Essays in the Political Economy of Australian Capitalism, but Wheelwright and Buckley saw it as the sixth volume of the series de facto, with a new publisher, and concentrating on one major theme, as some of the reviewers had suggested could be done in some future volumes.

14 Some of the more recent radical histories of Australian capitalism that Buckley and Wheelwright potentially had access to (for the pre-1960s period), include the publications in many of the good journals (such as Labour History) plus Peter Cochrane's (1980) material that emerged in Industrialization and Dependence, R. W. Connell and T H. Irving's Class Structure and Australian History (1980), and Kosmas Tsokhas's Markets, Money and Empire (1990). Later work by Andrew Wells (1989) emerged too late to be included, at least in the finished, complete version, for the first volume of the history.

15 Ken Buckley (2008, p. 333) notes that 'the division of labour between the pair of us was that I would write most of it, while Ted was responsible for overseeing matters of economic interpretation as well as writing an Introduction which summarised the contents of the book. Of course, we discussed particular points of presentation, but we never had a major difference of opinion'. Frank Stilwell (2009) thinks Wheelwright may have written more than Buckley acknowledges here, although Wheelwright (1990 p. 116) did say that he and Buckley had a 'division of labour' (agreement) whereby ELW would complete volume 6 of the edited books on the political economy of 
Australia capitalism (on the media) while Buckley drafted 'most of the Oxford volume one history'. Little further information is available about the division of labour, including for the second volume.

16 Because the authors had problems with the publisher for the second volume, False Paradise, few (if any) copies were sent to journals for review, and it was remaindered very early on (Wheelwright \& Kuhn 1990, Buckley 2008). This is a shame and really a new publisher needs to be found to put the book back into circulation and gain the required journal scrutiny of reviewers (preferably publishing both volumes as one). Also, someone needs to update the material to the 2000 s by writing a third volume, where the earlier periods are perhaps briefly summarised.

\section{References}

Baran, P. A., and Sweezy, P. M. 1965. Monopoly Capital. New York: Monthly Review. Reprinted in subsequent years by Penguin.

Bello, Walden. 2008. 'Towards a new American isolationism: an Asian viewpoint', Journal of Australian Political Economy 62, December, pp. 5-15. (The First Ted Wheelwright Memorial Lecture).

Berle, Adolf A., and Gardiner C. Means. 1932. The Modern Corporation and Private Property. New York: Harcourt, Brace and World, 1968.

Buckley, Ken. 2008. Buckley's! Ken Buckley; Historian, Author and Civil Libertarian: An Autobiography. Sydney: A\&A Book Publishing.

Buckley, Ken, and Edward Lawrence Wheelwright. 1988. No Paradise for Workers: Capitalism and the Common People in Australia, 1788-1914. Sydney: Oxford University Press.

Buckley, Ken, and Edward Lawrence Wheelwright. 1998. False Paradise: Australian Capitalism Revisited: 1915-1955. Sydney: Oxford University Press.

Cochrane, Peter. 1980. Industrialization and Dependence: Australia's Road to Economic Development. Brisbane: University of Queensland Press.

Collins, Jock. 2009. 'Recollections of Traumatic Times', in Gavan Butler, Evan Jones and Frank Stilwell (eds), Political Economy Now! The Struggle for Alternative Economics at the University of Sydney. Sydney: Darlington Press, pp. 50-3.

Connell, R. W., and T.H. Irving. 1980. Class Structure in Australian History: Documents, Narrative and Argument. Melbourne: Cheshire.

Crough, Greg, and Edward Lawrence Wheelwright. 1982. Australia: A Client State. Harmondsworth: Penguin.

Crough, Greg, Edward Lawrence Wheelwright and Ted Wilshire, (eds). 1980. Australia and World Capitalism. Harmondsworth: Penguin.

David, Abe, and Ted Wheelwright. 1989. The Third Wave: Australia and Asian Capitalism. Sydney: Left Book Club Cooperative Ltd.

Fitzpatrick, Brian. 1939. British Imperialism and Australia. Melbourne: Melbourne University Press, 1966.

Fitzpatrick, Brian. 1941. The British Empire in Australia, 1834-1939. Melbourne: Macmillan, 1969. Foreword by Geoffrey Blainey.

Fitzpatrick, Brian, and Edward Lawrence Wheelwright. 1965. The Highest Bidder: A Citizen's Guide to Problems of Foreign Investment in Australia. Melbourne: Landsdowne Press. 
Galbraith, John Kenneth. 1967. The New Industrial State. Harmondsworth: Penguin, 1982.

Groenewegen, P. D. 1979. 'Radical Economics in Australia: A Survey of the 1970s, in F. H. Gruen (ed.), Surveys of Australian Economics. Volume II. Sydney: Allen \& Unwin, pp. 170-223.

Gurevitch, Michael, T. Bennett, C. Curran and J. Wollacott (eds). 1981. Culture, Society and Media. London: Methuen.

Hunter, Alex, (ed.). 1963. The Economics of Australian Industry: Studies in Environment and Structure. Melbourne: Melbourne University Press.

Jones, Evan, and Frank Stilwell. 1986. 'Political Economy at the University of Sydney', in Brian Martin et al. (eds), Intellectual Oppression. Sydney: Angus \& Robinson, pp. 30-51.

Karmel, P.H., and Brunt, Maureen. 1963. The Structure of the Australian Economy. Melbourne: Cheshire.

Mizruchi, Mark S. 2004. 'Berle and Means revisited: the governance and power of large U.S. corporations', Theory and Society 33, pp. 579-617.

Murray, Georgina. 2001. 'Interlocking directorates: what do they tell about corporate power in Australia?', Journal of Australian Political Economy 47 , pp. 5-26.

Neale, Walter C. 1991. 'Society, state and market: a Polanyian view of current change and turmoil in Eastern Europe', Journal of Economic Issues 25(2), June, pp. 467-73.

O'Hara, Phillip Anthony. 1975. A Study of Economic Power in the Brewery Industry in Perth. Thesis for BA(SocSc). Western Australian Institute of Technology (WAIT) (Forerunner of Curtin University). 65pp. Supervised by Robert Greig. Department of Social Sciences. (A thesis, taking one year to complete, was a required part of the 3-year undergraduate degree.)

O'Hara, Phillip Anthony. 2006. Growth and Development in the Global Political Economy: Social Structures of Accumulation and Modes of Regulation. Oxford and New York: Routledge.

Playford, John, and Douglas Kirsner, (eds). 1972. Australian Capitalism: Towards a Socialist Critique. Harmondsworth: Penguin.

Polanyi, Karl. 1944. The Great Transformation. Boston: Beacon Press, 1968.

Rolfe, Hilda. 1967. The Controllers: Interlocking Directorships in Large Australian Companies. Melbourne: F. W. Cheshire. Introduction by E. L. Wheelwright.

Rosewarne, Stuart. 2009. 'Re: ELW', Email from Stuart Rosewarne to Phil O'Hara, 6 July.

Schutz, Eric. 2001a. 'Economic Power', in Phillip Anthony O'Hara, Encyclopedia of Political Economy. London \& New York: Routledge, pp. 245-9.

Schutz, Eric. 2001b. Markets \& Power: The 21 $1^{\text {st }}$ Century Command Economy. Armonk, New York: M. E. Sharpe, Inc.

Stanfield, James Ronald. 1986. The Economic Thought of Karl Polanyi: Lives and Livelihood. London: Macmillan, and New York: St. Martin's.

Stanford, Jim. 2009. 'Beyond the Economic Crisis: How the Economic System Can be Changed', 2009 Ted Wheelwright Memorial Lecture. University of Sydney. 20 August. 
Stauffer, Robert B. 1988. The Philippines Under Marcos: Failure of Transnational Developmentalism: Transnational Corporations in South East Asia and the Pacific, Volume 9. Sydney: TCRP, University of Sydney.

Stilwell, Frank. 2007. 'E. L. Wheelwright, 1921-2007', Journal of Australian Political Economy 60, pp. 130-6. (A similar document was also published as an 'Obituary' in Labour History, Volume 93, 2007).

Stilwell, Frank. 2009. Comments about E. L. Wheelwright to Phil O'Hara. Written communication.

SUW (Sydney University World). 2008. The Inaugural Ted Wheelwright Memorial Lecture. Available on the Internet.

TCRP (Transnational Corporations Research Project). 1989. List of Publications. TCRP Research Institute, Department of Geography, University of Sydney. 12 January (includes handwritten additions).

Tsokhas, Kosmas. 1990. Markets, Money and Empire: The Political Economy of the Australian Wool Industry. Melbourne: Melbourne University Press.

Utrecht, Ernst. 1978a. Transnational Corporations in South East Asia and the Pacific, Volume 1. Sydney: TCRP, University of Sydney. (With contributions by Kate Short.)

Utrecht, Ernst. 1978b. Transnational Corporations in South East Asia and the Pacific, Volume 2. Sydney: TCRP, University of Sydney. (With contributions by Malcolm Caldwell.)

Utrecht, Ernst, (ed.). 1981. Transnational Corporations in South East Asia and the Pacific, Volume 3. Sydney: TCRP, University of Sydney.

Utrecht, Ernst, (ed.). 1982. Transnational Corporations in South East Asia and the Pacific, Volume 4. Sydney: TCRP, University of Sydney.

Utrecht, Ernst, (ed.). 1983. Transnational Corporations in South East Asia and the Pacific, Volume 5. Sydney: TCRP, University of Sydney.

Utrecht, Ernst, (ed.). 1984. Fiji: Client State of Australasia? Transnational Corporations in South East Asia and the Pacific, Volume 6. Sydney: TCRP, University of Sydney.

Utrecht, Ernst. 1986. Transnational Corporations and Export-Oriented Industrialisation: Transnational Corporations in South East Asia and the Pacific, Volume 7. Sydney: TCRP, University of Sydney.

Van Ness, Peter. 1971. 'Review of The Chinese Road to Socialism', Annals of the American Academy of Political and Social Science 398, pp. 159-60.

Veblen, Thorstein Bunde. 1905. The Theory of Business Enterprise. New York: Kelley, 1968.

Veblen, Thorstein Bunde. 1923. Absentee Ownership. New York: Kelley, 1970.

Veblen, Thorstein Bunde. 1994. The Collected Works of Thorstein Veblen. London and New York: Routledge. Edited by Peter Cain. 10 volumes.

Waterhouse, Richard. 2002. 'Review of False Paradise', Labour History 83, November, pp. 243-5.

Wells, Andrew. 1989. Constructing Capitalism: An Economic History of Eastern Australia, 1788-1901. Sydney: Allen \& Unwin.

Wheelwright, Edward Lawrence. 1957. Ownership and Control of Australian Companies: A Study of 102 of the Largest Public Companies Incorporated in Australia. Sydney: Law Book Company of Australia. 
Wheelwright, Edward Lawrence. 1963. 'Overseas Investment in Australia', in Alex Hunter (ed.), The Economics of Australian Industry: Studies in Environment and Structure. Melbourne: Melbourne University Press.

Wheelwright, Edward Lawrence. 1970. 'Concentration of private economic power', Arena: An Independent Marxist Journal 23, pp.1-22. (Based on Wheelwright's 1970 Brian Fitzpatrick Memorial Lecture.) Reprinted in Playford and Kirsner (1972) and Wheelwright (1974a).

Wheelwright, Edward Lawrence. 1974a. Radical Political Economy: Collected Essays. Sydney: ANZ Book Company.

Wheelwright, Edward Lawrence. 1974b. 'Capitalism and Social Decay" ABC broadcast, reprinted in ABC, Heresies. Sydney: Australian Broadcasting Commission.

Wheelwright, Edward Lawrence. 1978. Capitalism, Socialism or Barbarism? The Australian Predicament: Essays in Contemporary Political Economy. Sydney: ANZ Book Company.

Wheelwright, Edward Lawrence. 1987. 'The world of debt and the flights of capital', Arena 80, pp. 19-29.

Wheelwright, Edward Lawrence, (ed.). 1988. Consumers, Transnational Corporations and Development: Transnational Corporations in South East Asia and the Pacific, Volume 8. Sydney: TCRP, Sydney University.

Wheelwright, Edward Lawrence. 1991a. 'Oil and the World Economy', Arena 95, pp. 41-6.

Wheelwright, Edward Lawrence. 1991b. 'The Great Depression of the 1990s', Arena 96, pp. 94-102.

Wheelwright, Edward Lawrence. 1992. 'Global Capitalism Now: Depression in the 1990s', Arena 98, pp. 63-73.

Wheelwright, Edward Lawrence. 1995. 'Why has economics become so conservative?', Journal of Economic and Social Policy 1(1), pp. 21-8.

Wheelwright, Edward Lawrence. 1997. 'Political constipation and vested interests: the Scott and Jackson Committees of Inquiry", Journal of Economic and Social Policy 2(1), Summer, pp. 20-27.

Wheelwright, Edward Lawrence. 1998-2006. Political Economy Newsletter. University of Sydney; Transnational Corporations Research Project, Departments of Geography/Geosciences.

Wheelwright, Edward Lawrence. 2000. 'Wheelwright (Ted) (born 1921)', in Phillip Arestis and Malcolm Sawyer (eds), A Biographical Dictionary of Dissenting Economists. Second edition. Cheltenham, UK and Northampton, MA: Edward Elgar.

Wheelwright, Edward Lawrence. 2001a. 'Economic Rationalism or Liberalism', in Phillip Anthony O'Hara (ed.), Encyclopedia of Political Economy, Volume 1. London and New York: Routledge, pp. 249-51. Paperback edition.

Wheelwright, Edward Lawrence. 2001b. 'Global Corporate Capitalism”, in Phillip Anthony O'Hara (ed.), Encyclopedia of Political Economy, Volume 1. London and New York: Routledge, pp. 403-6. Paperback edition.

Wheelwright, Edward Lawrence, and Ken Buckley, (eds). 1975. Essays in the Political Economy of Australian Capitalism: Volume One. Sydney: ANZ Book Company. 
Wheelwright, Edward Lawrence, and Ken Buckley, (eds). 1978. Essays in the Political Economy of Australian Capitalism: Volume Two. Sydney: ANZ Book Company.

Wheelwright, Edward Lawrence, and Ken Buckley, (eds). 1978. Essays in the Political Economy of Australian Capitalism: Volume Three. Sydney: ANZ Book Company.

Wheelwright, Edward Lawrence, and Ken Buckley, (eds). 1980. Essays in the Political Economy of Australian Capitalism: Volume Four. Sydney: ANZ Book Company.

Wheelwright, Edward Lawrence, and Ken Buckley, (eds). 1983. Essays in the Political Economy of Australian Capitalism: Volume Five. Sydney: ANZ Book Company.

Wheelwright, Edward Lawrence, and Ken Buckley, (eds). 1987. Communications and the Media in Australia. Sydney: Allen \& Unwin.

Wheelwright, Edward Lawrence, and Rick Kuhn. 1990. Recorded Interview with Edward Lawrence Wheelwright by Rick Kuhn. Canberra: National Library of Australia. Oral History Collection. 12 June. TRC-2592 (Five Cassettes and Transcript).

Wheelwright, Edward Lawrence, and Bruce McFarlane. 1969. The Chinese Road to Socialism: Economics of the Cultural Revolution. New York and London: Monthly Review Press. Foreword by Joan Robinson.

Wheelwright, Edward Lawrence, and Judith Miskelly. 1967. Anatomy of Australian Manufacturing Industry: The Ownership and Control of 300 of the Largest Manufacturing Companies in Australia. Sydney: Law Book Company.

Wheelwright, Edward Lawrence, and Albert Moran. 1990. 'Writing non-fiction: an interview with E. L. Wheelwright [by Albert Moran]', Continuum 4(1), pp. 109-17.

Wheelwright, Edward Lawrence, and Frank J. B. Stilwell, (eds). 1976a. Readings in Political Economy: Volume One. Sydney: ANZ Book Company.

Wheelwright, Edward Lawrence, and Frank J. B. Stilwell, (eds). 1976b. Readings in Political Economy: Volume Two. Sydney: ANZ Book Company.

Yahoo Answers. 2009. Distinguished Flying Cross. Available Online. 